\title{
PENGARUH pH DAN WAKTU PENYIMPANAN TERHADAP PERTUMBUHAN Lasiodiplodia theobromae PENYEBAB KANKER BATANG TANAMAN KARET
}

\author{
Effect of $\mathrm{pH}$ and Storage Period to the Growth of Lasiodiplodia theobromae which \\ Causes the Stem Canker on the Rubber Plant
}

\author{
Tri Rapani FEBBIYANTI ${ }^{1 *}$, WIDODO ${ }^{2}$, Suryo WIYONO $^{2}$, dan Sudirman YAHYA $^{3}$ \\ ${ }^{1)}$ Balai Penelitian Sembawa - Pusat Penelitian Karet \\ Jalan Raya Palembang - Betung KM 29 \\ Palembang 30001 Sumatera Selatan \\ *E-mail : irri_sbw@yahoo.com \\ ${ }^{2)}$ Program Studi Fitopatologi, Departemen Proteksi, \\ Fakultas Pertanian Institut Pertanian Bogor \\ Kampus IPB Dramaga Bogor Jawa Barat \\ ${ }^{3)}$ Program Studi Agronomi dan Hortikultura \\ Fakultas Pertanian Institut Pertanian Bogor \\ Kampus IPB Dramaga Bogor Jawa Barat
}

Diterima : 14 Mei 2019 / Disetujui : 18 Juni 2019

\begin{abstract}
Stem canker caused by the fungus Lasiodiplodia theobromae on rubber plant (Hevea brasiliensis Muell Arg.) is a new disease and has not yet been reported in Indonesia. Many ways can be done to control stem canker. The best control strategy is the management of diseases that require knowledge of the ecology of pathogens, host, and their interactions with biotic and abiotic environments. Control of pathogen should be based on knowledge of their bioecology. It is hoped that bioecological knowledge can be used as a basis to inhibit the development or decrease inoculum population in the field. This study aimed to determine the effect of $\mathrm{pH}$ in vitro on the growth of stem canker pathogen and the rate of decreased viability due to storage. The range of effect of $\mathrm{pH}$ media were 3, 4, 5, 6 and 7 . Fruit body storage was carried out in containers without soil, sterile soils and unsterilized soil. The determination of viability was carried out at $30,60,90$, and 120 days of storage. The lower the $\mathrm{pH}$ was causing the mycelial growth to be inhibited. Decreased the viability of the fruit body was fastest when it was stored in unsterilized soil as a result of tissue decay and attacked by antagonist fungi.
\end{abstract}

Keywords : Bioechology; $p H$; storage; viability
Abstrak

Lasiodiplodia theobromae merupakan cendawan penyebab kanker batang pada tanaman karet (Hevea brasiliensis Muell Arg.), penyakit ini merupakan penyakit baru dan belum pernah dilaporkan sebelumnya di Indonesia. Banyak cara yang dapat dilakukan untuk mengendalikan penyakit kanker batang. Strategi pengendalian yang terbaik adalah dengan pengelolaan penyakit yang membutuhkan pengetahuan mengenai ekobiologi patogen, inang, dan interaksinya dengan lingkungan biotik dan abiotik. Pengendalian patogen harus didasarkan pada pengetahuan tentang bioekologinya. Diharapkan dengan pengetahuan bioekologi bisa dijadikan dasar untuk bisa menghambat perkembangan atau menurunkan populasi inokulum di lapangan. Penelitian ini bertujuan untuk menentukan pengaruh $\mathrm{pH}$ secara in vitro terhadap pertumbuhan patogen kanker batang dan laju penurunan viabilitas tubuh buah akibat penyimpanan. Kisaran pengaruh pH media meliputi 3, 4, 5, 6, dan 7 . Penyimpanan tubuh buah dilakukan dalam wadah tanpa diberi tanah, diberi tanah steril dan tanah tidak steril. Penentuan viabilitas dilakukan pada 30, 60, 90, dan 120 hari masa penyimpanan. Semakin rendah $\mathrm{pH}$ 
menyebabkan pertumbuhan miselia terhambat.

Kata kunci: Bioekologi; penyimpanan; pH; viabilitas

\section{PENDAHULUAN}

L. theobromae merupakan cendawan penyebab kanker batang pada tanaman karet (Hevea brasiliensis Muell Arg.), penyakit ini merupakan penyakit baru dilaporkan sebelumnya di Indonesia (Febbiyanti et al, 2019). Saat ini, kanker batang ditemukan dan merusak perkebunan karet di Sumatera Selatan (Febbiyanti, 2017). Selanjutnya, Pengendalian patogen penyebab penyakit harus didasarkan pada pengetahuan tentang bioekologinya. Diharapkan dengan pengetahuan bioekologi bisa dijadikan dasar untuk bisa menghambat perkembangan atau menurunkan populasi inokulum di lapangan. Penelitian ini bertujuan untuk menentukan pengaruh $\mathrm{pH}$ terhadap laju penurunan viabilitas akibat penyimpanan karena viabilitas akan mempengaruhi kemampuan tumbuh patogen di lapangan yang bisa menjadi sumber inokulum.

Perkembangan penyakit erat kaitannya dengan faktor lingkungan fisik. Suhu, $\mathrm{pH}$, dan kandungan amoniumnitrogen dapat mempengaruhi perkecambahan Basidiospora coprinopsis spp. Pengaruh yang terjadi berbeda di antara spesies yang diambil dari beberapa lokasi (Raut et al., 2011). Selain itu pH dan suhu juga dapat mempengaruhi pertumbuhan dan kerapatan aservuli yang dibentuk oleh Colletotrichum coccodes (Nizan \& Tsror, 2003). Tanggap terhadap faktor fisik lingkungan penting dalam rangka usaha kita untuk mengendalikan serangan patogen. Berdasarkan hal itu maka kajian pengaruh lingkungan fisik terhadap perkembangan patogen kanker batang penting dikaji. Penelitian ini juga bertujuan untuk menentukan pengaruh $\mathrm{pH}$ terhadap pertumbuhan in vitro patogen kanker batang dan laju penurunan viabilitas patogen akibat penyimpanan, hasil penelitian diharapkan dapat dijadikan pertimbangan dalam menentukan strategi pengendalian yang efektif.

\section{BAHAN DAN METODE}

\section{Pengujian Perlakuan pH terhadap Pertumbuhan $L$. theobromae}

Pengujian dilakukan pada media PDA yang dituang dalam cawan petri ukuran diameter $9 \mathrm{~cm}$. Untuk perlakuan digunakan 5 isolat biakan yang berumur 4 hari setelah inokulasi, sumber isolat merupakan koleksi Balai Penelitian Sembawa. Pengaturan $\mathrm{pH}$ media PDA sesuai dengan perlakuan, yaitu dengan penambahan larutan $\mathrm{HCl} 2 \%$ yang dilakukan sebelum sterilisasi media sehingga diperoleh $\mathrm{pH}$ akhir media menjadi 3, 4, 5, 6, dan 7. Percobaan dirancang dalam Rancangan Acak Lengkap dan setiap perlakuan diulang 10 kali. Nilai $\mathrm{pH}$ media ditentukan menggunakan $\mathrm{pH}$ meter.

Pada setiap media dalam cawan petri dengan masing-masing tingkat $\mathrm{pH}$ diletakkan potongan koloni biakan $L$. theobromae berumur 4 hari dengan ukuran diameter $\pm 1 \mathrm{~cm}$ di bagian tengah cawan. Pengamatan perkembangan pertumbuhan radial cendawan uji dilakukan setiap hari sampai salah satu cawan dipenuhi oleh koloni cendawan. Data dianalisis dengan menggunakan program SAS.

\section{Viabilitas Patogen Akibat Penyimpanan}

Untuk menentukan kemampuan bertahan patogen diperlukan potongan cabang batang tanaman karet yang bergejala kanker batang dan nekrosis kulit. Ukuran bercak gejala yang digunakan berkisar 20$25 \mathrm{~cm}$, sehingga potongan cabang yang digunakan berukuran $20-25 \mathrm{~cm}$.

Penyimpanan potongan cabang batang karet bergejala dilakukan dalam wadah plastik ukuran 45 × 25 × 20 cm (p x 1 x t). Perlakuan penyimpanan terdiri atas tanpa diberi tanah, diberi tanah steril, dan tanah tidak steril. Sterilisasi tanah dilakukan 2 kali berturut-turut dengan uap panas bertekanan dalam otoklaf masing-masing perlakuan diulang $3 \mathrm{kali}$, dimana setiap unit perlakuan terdiri atas 10 potong tanaman yang terinfeksi patogen uji.

Penyimpanan semua perlakuan dilakukan dalam ruangan atau kamar tertutup pada suhu $27-30^{\circ} \mathrm{C}$. Selama masa 
penyimpanan kelembapan tanah dipertahankan antara 60-70\% dengan cara menyemprotkan aquades steril menggunakan penyemprot tangan (hand sprayer). Penyemprotan dilakukan jika kelembapan tanah di bawah $60 \%$ yang diukur dengan menggunakan soil tester.

Pengamatan variabel viabilitas cendawan pada potongan cabang batang dilakukan dengan menumbuhkan potongan gejala pada media PDA. Untuk itu terlebih dahulu potongan cabang yang disimpan di dalam tanah dibongkar dan dibersihkan dari partikel tanah yang melekat. Potongan tanaman sakit sebanyak 10 potong setiap perlakuan dicuci dengan merendam dalam larutan kloramfenikol 200 ppm selama 2 menit sambil dikocok dan kemudian direndam dalam alkohol $70 \%$ selama 3 menit dengan cara yang sama. Terakhir potongan tanaman yang sakit tersebut dibilas dengan menggunakan aquades steril dengan cara direndam sambil dikocok selama 3 menit. Sebelum diinokulasi pada media PDA potongan tanaman sakit dikeringkan menggunakan kertas isap. Penentuan viabilitas dilakukan pada 30,60, 90 dan 120 hari setelah masa penyimpanan. Ketahanan hidup ditentukan dengan menghitung \% potongan kayu yang ditumbuhi cendawan $L$. theobromae.

\section{HASIL DAN PEMBAHASAN}

\section{Pengujian pH terhadap Pertumbuhan $L$. theobromae}

Pertumbuhan koloni L. theobromae pada $\mathrm{pH}$ 3, 4, 5, 6 dan 7 menunjukkan pertumbuhan yang berbeda (Gambar 1). Pada Gambar 1 terlihat, semakin rendah $\mathrm{pH}$ atau keasaman media yang semakin tinggi maka diameter koloni semakin kecil atau pertumbuhan miselium lebih lambat. Pada pH 3 terlihat bahwa pertumbuhan koloni $L$. theobromae memenuhi petri pada umur biakan lima hari, sedangkan pada $\mathrm{pH} 6$ miselium memenuhi cawan petri pada umur biakan tiga hari dan tidak terlihat perbedaan pertumbuhan miselium $L$. theobromae pada $\mathrm{pH} 6$ dan $\mathrm{pH}$ 7, dimana pertumbuhan miselium pada $\mathrm{pH} 6$ maupun 7 tumbuh dengan cepat dengan diameter koloni mencapai 1,3 - $2 \mathrm{~cm}$ Miselia tumbuh seperti kapas dengan miselium udara yang tumbuh memenuhi cawan (Gambar 3) dan (Gambar
4). Karakter koloni cendawan L. theobromae pada $\mathrm{pH} 6$ dan 7 ini sama seperti yang diuraikan oleh Punithalingam (1976), yaitu pertumbuhan miselia seperti benang halus atau kapas, miselium udara berlimpah. Koloni mula-mula berwarna sepia berubah menjadi abu-abu kemudian menjadi hitam.

Pengaruh $\mathrm{pH}$ media juga terlihat dari hasil analisis keragaman yang dilakukan (Gambar 2). Hasil regresi pengaruh $\mathrm{pH}$ media menunjukkan pertumbuhan optimum terjadi pada $\mathrm{pH}$ sekitar 5,65. Persamaan regresi antara pH media dengan pertumbuhan radial $L$.theobromae adalah y = $-4.807+3.21 \mathrm{x}-0.2843 \mathrm{x}^{2}$. Temuan ini sesuai dengan Pardo et al. (2006) yang menyatakan bahwa $\mathrm{pH}$ atau konsentrasi ion Hidrogen dalam suatu media berpengaruh langsung bagi pertumbuhan jamur dengan mempengaruhi sel atau secara tidak langsung dengan mempengaruhi ketersediaan nutrisi, dan kisaran $\mathrm{pH}$ bagi pertumbuhan jamur cukup luas, berkisar dari $\mathrm{pH}$ 3,0 hingga lebih dari $\mathrm{pH} 8,0$, dengan $\mathrm{pH}$ optimum sekitar 5,0 jika kebutuhan nutrisi terpenuhi. Kemudian, pertumbuhan Aspergillus carbonarius dari anggur lebih baik pertumbuhannya pada $\mathrm{pH}$ 4,0 dan 7,0 dari pada $\mathrm{pH} 2$, dan 6 , dan secara umum spesies Aspergillus lebih banyak toleran terhadap $\mathrm{pH}$ basa sedangkan spesies Penicillium lebih toleran terhadap $\mathrm{pH}$ asam (Wheeler $\mathrm{K}$ et al., 1991). Kemudian pertumbuhan miselia dan pembentukan spora terjadi pada $\mathrm{pH} 5,5$ dan $\mathrm{pH}$ 6,5 dalam media cair (Saha et al., 2008 ; Deshmukh et al., 2012).

Warna koloni pada masing-masing pH media tidak berbeda (Gambar 3). Warna koloni berwarna putih abu pada hari pertama umur biakan dan terus bertambah hitam seiring dengan bertambahnya umur koloni, kemudian bentukan konidia juga tidak berbeda pada masing-masing $\mathrm{pH}$. Kemasaman media akan mempengaruhi ketersediaan mineral dan nutrisi yang dapat diserap oleh cendawan, dan juga kerja enzim yang dihasilkan cendawan dalam membantu menghancurkan substrat yang dapat dimanfaatkan untuk pertumbuhannya. Pada penelitian Saha et al. (2008) dengan $\mathrm{pH}$ 3-8 terlihat bahwa $L$. theobromae tumbuh optimum pada $\mathrm{pH} 6$ yang ditumbuhkan pada media PDA yang ditambah dengan ekstrak akar teh. Kemasaman $(\mathrm{pH})$ suatu media atau substrat tumbuh juga berpengaruh 


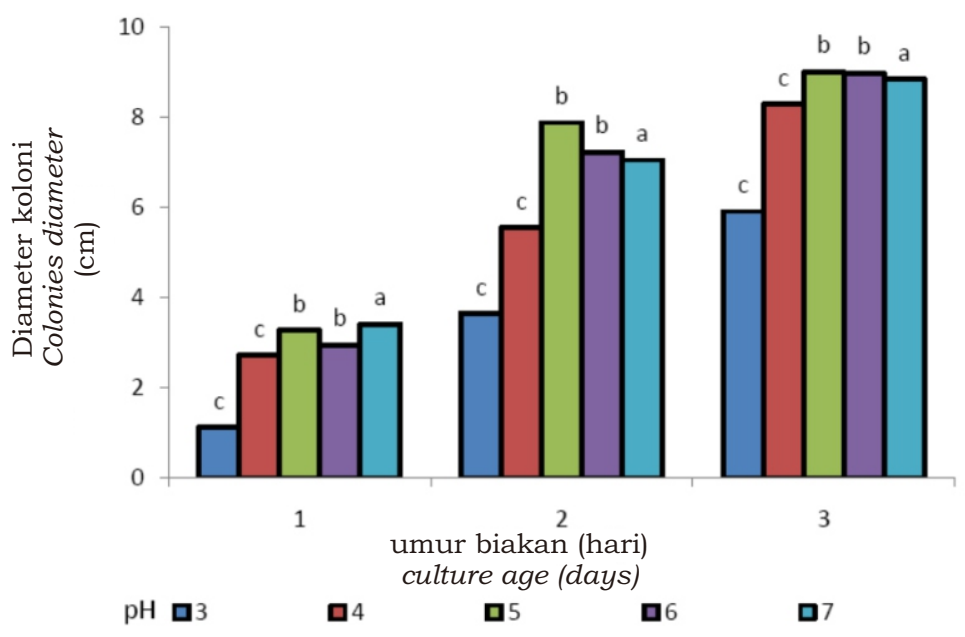

Gambar 1. Pertumbuhan koloni cendawan $L$. theobromae pada berbagai pH media PDA Figure 1. Growth of $L$. theobromae fungus colonies at various $p H$ of PDA media

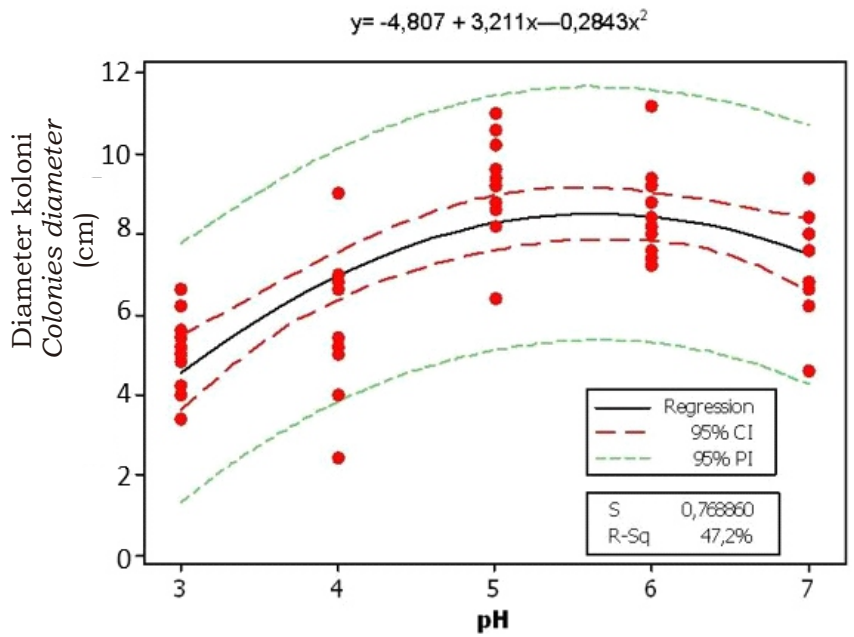

Gambar 2. Pengaruh $\mathrm{pH}$ media PDA terhadap pertumbuhan koloni L. theobromae Figure 2. Effect of $p H$ of PDA media to growth of $L$. theobromae colonies

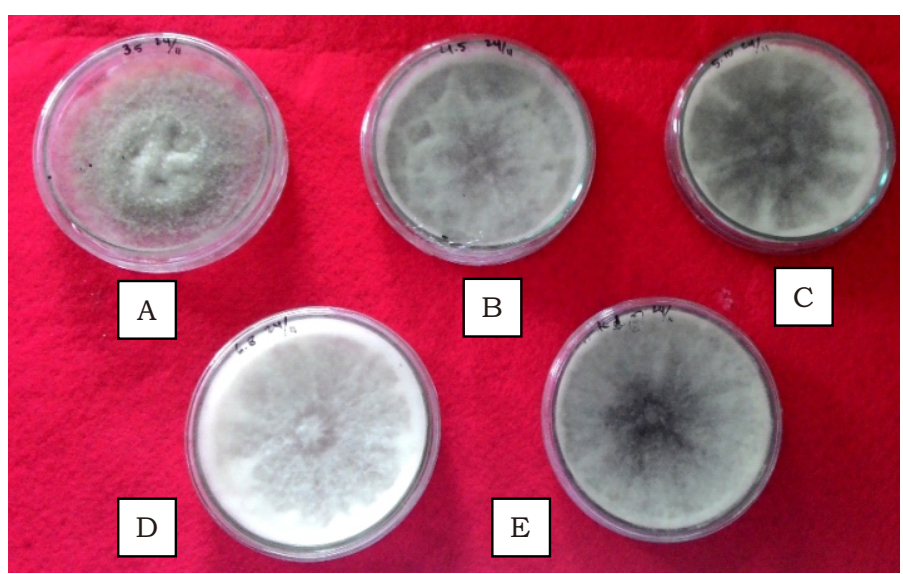

Gambar 3. Warna koloni $L$. theobromae pada masing-masing $\mathrm{pH}$ umur biakan 8 hari (A) $\mathrm{pH} 3$, (B) $\mathrm{pH} 4$, (C) $\mathrm{pH} 5$, (D) $\mathrm{pH} 6$, (E) $\mathrm{pH} 7$

Figure 3. Color of L. theobromae colonies in each $p H$ at age of culture on 8 days $(A) p H 3,(B) p H$ 4, (C) pH 5, (D) pH 6, (E) pH 7 


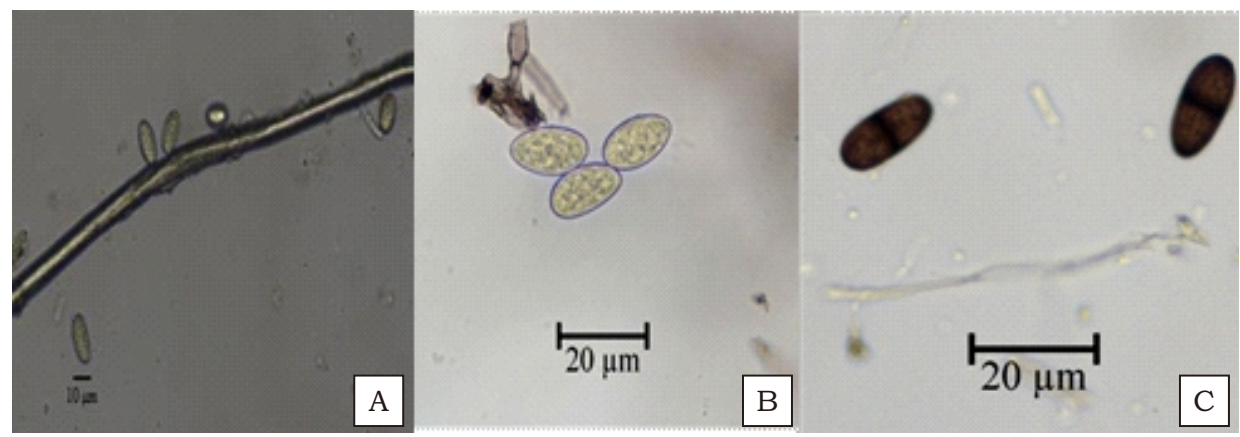

Gambar 4. Miselia dan konidia Lasiodiplodia theobromae. (A) miselium (B) konidia muda, (C) konidia matang

Figure 4. Mycelia and conidia of Lasiodiplodia theobromae. (A) mycelia (B) immature conidia, (C) mature conidia

terhadap kerja enzim $\beta$-glukoksidase yang merupakan enzim pemecah sellulosa atau substrat yang terdapat pada $L$. theobromae. Bobot molekul $\beta$-glukoksidase lebih stabil pada $\mathrm{pH}$ 2.7-8, dan $\mathrm{pH}$ pada kisaran tersebut mengaktifkan 2 group yaitu grup karboksil dan grup imidazolium pronate sehingga berfungsi menjadi katalis (Umezurike, 1979). Pada Trichoderma reesei $\mathrm{pH}$ berperan dalam kemampuannya menghasilkan komponen enzim selulase (endoglukanase, eksoglukanase dan $\beta$ glukosida). Enzim ini digunakan untuk menghancurkan substrat yang mengandung selulosa (Li et al., 2013).

Selain memengaruhi aktivitas fisiologi cendawan, secara umum $\mathrm{pH}$ juga dapat mepengaruhi ketersediaan nutrisi pada media tumbuh cendawan bersangkutan. Jika lingkungan media tumbuh cendawan tergolong masam $(\mathrm{pH} \leq 4)$ menyebabkan beberapa nutrisi seperti $\mathrm{K}, \mathrm{S}$, $\mathrm{Mo}, \mathrm{N}, \mathrm{Ca}, \mathrm{Mg}$, dan $\mathrm{P}$ menjadi kurang bisa dimanfaatkan oleh cendawan. Pengaruh tidak langsung dari $\mathrm{pH}$ adalah terhadap kinerja permukaan sel cendawan. Cendawan untuk dapat tumbuh baik memerlukan nutrisi dalam jumlah besar seperti $\mathrm{C}, \mathrm{H}, \mathrm{O}, \mathrm{N}, \mathrm{S}, \mathrm{P}, \mathrm{Mg}, \mathrm{K}$ di samping unsur mikro yang berguna sebagai kofaktor enzim dan protein fungsional (Carlile et al., 2001). Biasanya ketersediaan nutrisi akan tinggi jika $\mathrm{pH}$ media pada kondisi netral, yaitu berkisar antara 5.0 - 6.8. Secara umum, pH netral $(5,0-7,0)$ cocok untuk pertumbuhan miselia dan $\mathrm{pH} \mathrm{5,0-8,0} \mathrm{untuk}$ produksi konidial (Zhao et al., 2010). selanjutnya sporulasi miselia Aspergillus parasiticus lebih toleran terhadap kondisi asam dan netral, dan tertekan dalam kondisi basa, pertumbuhan miselia sangat dipengaruhi oleh pH media (Sibounavoun et al., 2009). Umumnya jamur berfilamen toleran terhadap $\mathrm{pH}$ asam dan kebanyakan dari mereka memiliki pH optimal antara 5,0 dan 6,0 untuk pertumbuhan sel dan beberapa kegiatan metabolisme (Rosfarizan et al., 2000). pada $\mathrm{pH} \mathrm{10,} \mathrm{berat} \mathrm{miselia}$ Alternaria solani paling tinggi dibandingkan Phytophthora capscici dan P. Cinnamomi, namun pada $\mathrm{pH} 11$, pertumbuhan ketiga jamur ini sudah terhambat (Kaiser et al., 2005).

Pengaruh $\mathrm{pH}$ pada media juga terjadi terhadap kelarutan anion atau kation, dan ini tentunya akan menentukan kemampuan absorpsi cendawan terhadap kelarutan anion atau kation. Pada $\mathrm{pH}$ netral kelarutan beberapa kation seperti $\mathrm{Fe}, \mathrm{Zn}$ dan $\mathrm{Ca}$ meningkat sehingga memudahkan diabsorpsi oleh cendawan. Jika $\mathrm{pH}$ masam maka penyerapan kation-kation oleh hifa terganggu, karena pada permukaan hifa akan di tempati oleh ion $\mathrm{H}$ (Cochran, 1958).

Memang berdasarkan penelitian ini, penekanan cendawan akibat kemasaman media belum bisa dimanfaatkan untuk pengendalian patogen ini, karena kemasaman tanah untuk pertumbuhan tanaman karet hampir sama yaitu antara $\mathrm{pH}$ 5-6. Namun informasi ini dapat digunakan untuk penelitian lanjutan mengetahui biekologi patogen ini yang berguna untuk pengendalian patogen Rosita et al. (2014) menyatakan bahwa faktor yang mempengaruhi keberadaan jenis jamur adalah keasaman tanah. Derajat keasaman tanah penting untuk pertumbuhan jamur, karena enzim-enzim tertentu hanya akan menguraikan suatu substrat sesuai dengan aktivitasnya pada $\mathrm{pH}$ tertentu. Hasil pengukuran $\mathrm{pH}$ tanah menunjukkan 
kisaran 5,4-6,8. Umumnya jamur tanah dapat tumbuh pada $\mathrm{pH}$ di bawah 7 (Gandjar et al., 1999). Waluyo (2007) juga menyatakan bahwa jamur memiliki rentang $\mathrm{pH}$ yang luas yaitu 2,0-8, 5 .

\section{Viabilitas Patogen Akibat Penyimpanan}

Perkembangan penyakit tanaman di lapangan sangat ditentukan oleh tersedianya sumber inokulum dan agensia penyebar. Penyakit kanker batang pada tanaman karet yang disebabkan oleh $L$. theobromae merupakan patogen tular tanah yang menyebar lewat konididan struktur bertahan yang disebut tubuh buah. Tubuh buah pada patogen ini adalah piknidia (Gambar 5). Namun, struktur bertahan yaitu tubuh buah ini akan semakin berkurang kemampuan tumbuhnya (viabiltas) akibat tekanan biotik ataupun abiotik.

Penyimpanan tubuh buah dari patogen penyebab kanker batang karet dapat menurunkan viabilitasnya (Gambar 6 dan 7). Semakin lama disimpan viabilitasnya menurun. Penurunan terbesar terjadi pada tubuh buah yang disimpan dalam tanah yang tidak disteril sebelumnya. Penyimpanan dalam tanah yang tidak disterilkan ternyata juga menyebabkan pembusukan cabang. Mikroba yang terdapat di tanah tidak saja menekan pertumbuhan cendawan sehingga menurunkan viabilitas, tetapi juga mempercepat pembusukan jaringan tanaman. Kemampuan hidup sebagai saprofitik akan berkurang karena cadangan makanan yang berasal dari jaringan dimanfaatkan oleh mikroorganisme lainnya yang berada di dalam tanah tidak disterilkan. Sennang et al. (2012) menjelaskan bahwa gula, asam amino dan asam organik berfungsi sebagai sumber energi dan makanan bagi jamur tanah. Keberadaan jamur tanah dipengaruhi oleh faktor lingkungan di habitat jamur, karena sifat jamur yang saprofit bergantung pada lingkungan dan bahan organik substrat. Faktor lingkungan yang mempengaruhi diantaranya keasaman tanah $(\mathrm{pH})$, suhu tanah, dan kelembaban tanah. Selanjutnya dijelaskan, mikroba antagonis mempunyai kemampuan dalam menghambat perkembangan patogen dengan berbagai mekanisme, antara lain melalui kompetisi ruang dan nutrisi, antibiosis dengan menghasilkan antibiotik tertentu berupa senyawa kimia yang mudah menguap (volatile) dan tidak menguap (non volatile) (Ajith \& Lakshmidevi, 2010) atau lytic enzyme (kitinase, protease, dan glukanase), parasitisme dengan melilit hifa patogen, dan induksi ketahanan tanaman (Agrios, 2005; Pal \& Gardener, 2006).

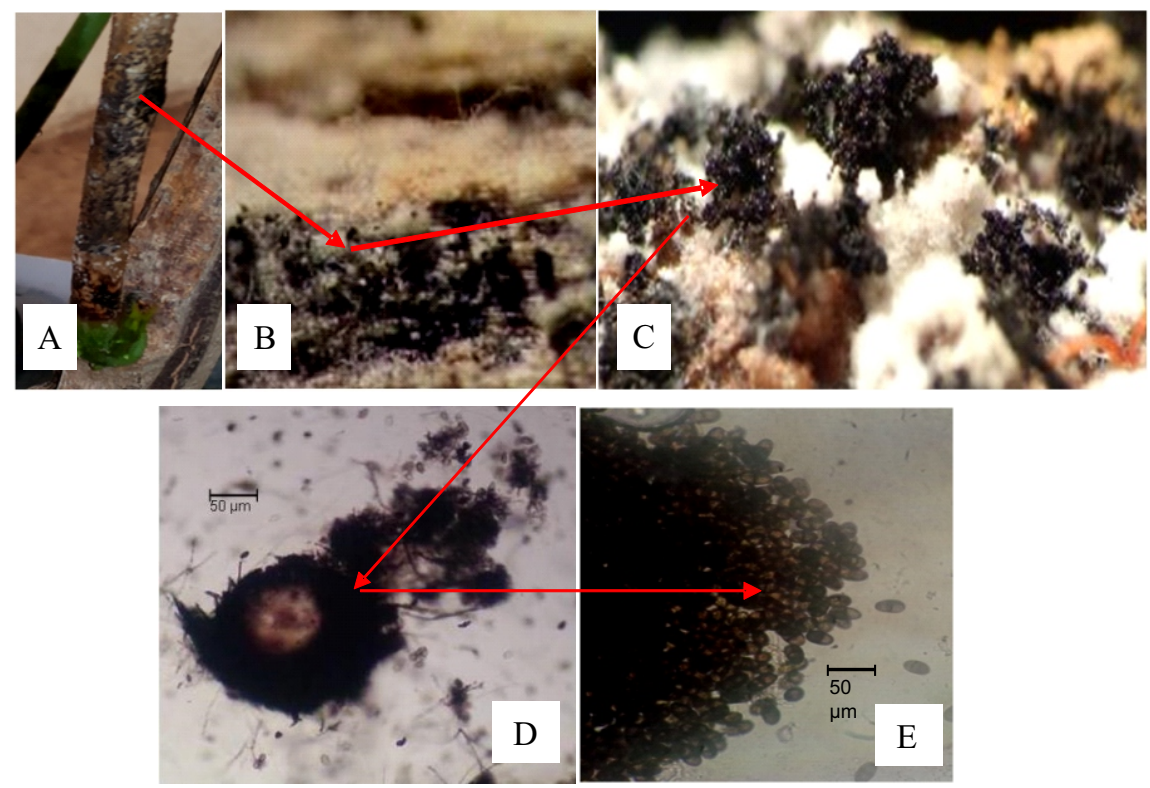

Gambar 5. Tubuh buah patogen (A) tanaman bergejala kanker batang, (B-D) tubuh buah patogen (piknidia), (E) konidia matang

Figure 5. $\quad$ Fruiting body of Pathogen (A) symptomatic plant stem cance (B-D) fruiting body (picnidia), (E) mature conidia 

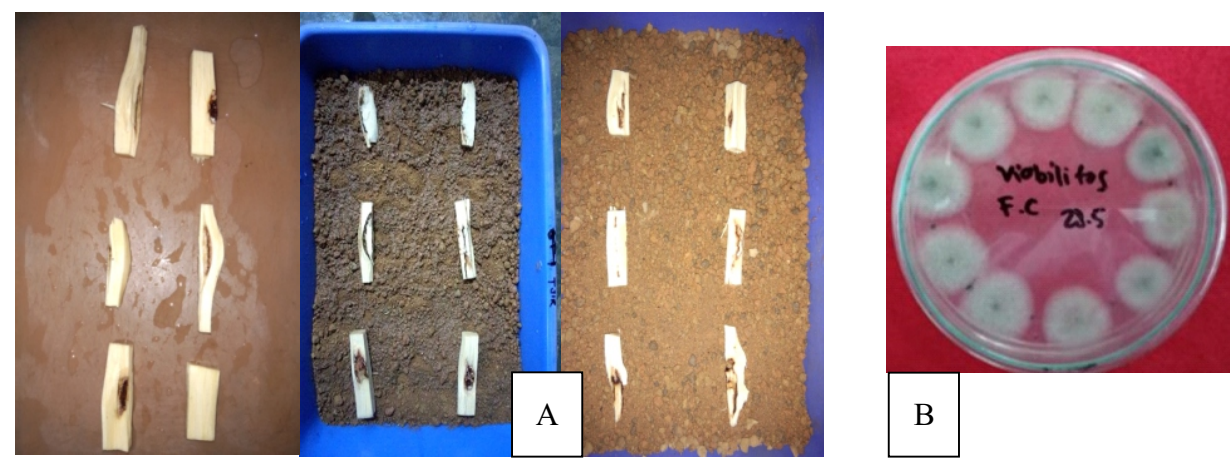

Gambar 6. Tubuh buah dan miselia L. theobromae (A) batang tanaman karet yang disimpan tanpa tanah, tanah steril dan tanah tidak steril, (B) viabilitas $L$ theobromae yang masih tumbuh $100 \%$

Figure 6. Fruiting body and mycelia L. theobromae (A) Rubber stems stored without soil, sterile soil and unsterile soil, (B) L theobromae viability which still growed 100\%

Pada perlakuan penyimpanan tanpa tanah juga menyebabkan penurunan viabilitas yang lebih cepat dibandingkan disimpan dalam tanah steril. Penyebab tidak tumbuh potongan tubuh buah pada media PDA dikarenakan cendawan lain yang bersifat antagonis tumbuh pada potongan tubuh buah. Berdasarkan pernyataan Soesanto (2008) dan Raka (2006), mekanisme kompetisi terjadi karena terdapat dua mikroorganisme yang secara langsung memerlukan sumber nutrisi yang sama, selanjutnya Purwantisari dan Hastuti (2009) menyatakan bahwa jamur yang dapat tumbuh dengan cepat mampu menguasai ruang media uji dan akhirnya dapat menekan pertumbuhan jamur lawannya.

Penurunan viabilitas diperkirakan dapat juga terjadi karena cekaman oleh lingkungan fisik. Tubuh buah yang disimpan tanpa tanah masih memungkinkan terjadi invasi oleh antagonis di permukaan tubuh buah patogen kanker batang, karena antagonis berkembang dengan memanfaatkan nutrisi yang ada pada permukaan tubuh buah. Smith dan Onions (1994), menjelaskan bahwa syaratsyarat untuk pertumbuhan bagi cendawan mungkin bervariasi dari satu jenis dengan jenis dari genus dan spesies lainnya. Akibat suhu udara yang tinggi, sekitar $30{ }^{\circ} \mathrm{C}$ dapat menyebabkan terjadi kehilangan air, baik pada tubuh buah cendawan dan jaringan tanaman. Kehilangan air yang terjadi bila berlangsung lama dapat menyebabkan selsel mengering dan mati. Pada jaringan tanaman yang mengalami kekeringan akan mengeras sehingga tidak memungkinkan untuk dapat dijadikan sumber energi bagi cendawan. Selain nutrisi untuk tumbuh dan berkembang cendawan memerlukan air yang digunakan dalam banyak reaksi metabolisme. Air merupakan komponen

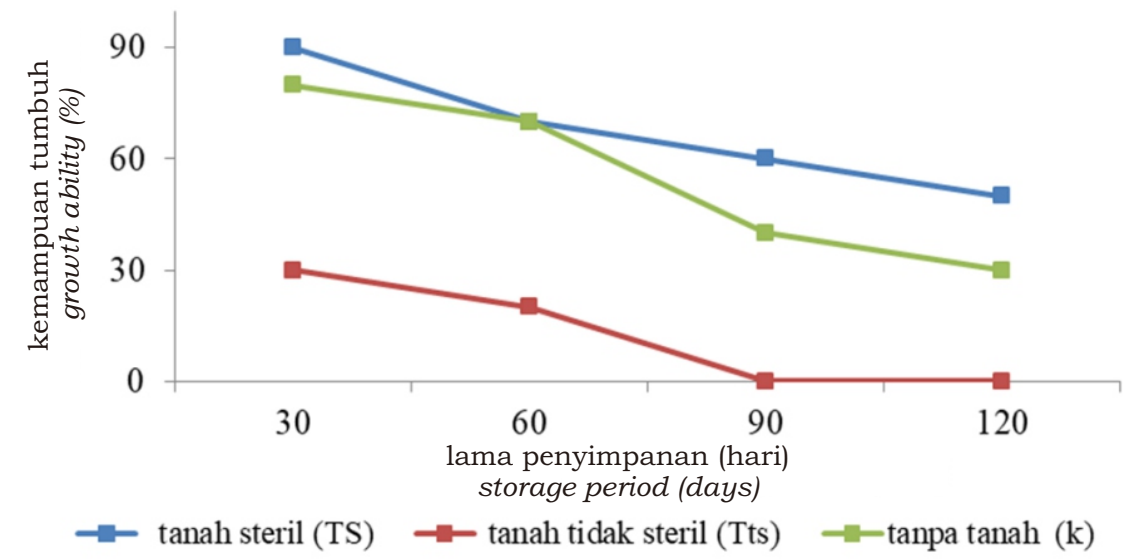

Gambar 7. Viabilitas tubuh buah $L$. theobromae selama masa penyimpanan

Figure 7. Viability of L. theobromae during the storage period 
utama protoplasma. Disamping itu merupakan wahana bagi masuknya nutrisi ke dalam sel dan keluarnya sekresi maupun ekskresi dari dalam sel, serta diperlukan untuk berlangsungnya reaksi enzimatik didalam sel (Fardiaz, 1987). Selain itu, suhu sangat penting dalam menentukan jumlah dan tingkat pertumbuhan. Peningkatan temperatur mempunyai efek yang umum dalam meningkatkan aktivitas enzim dan aktifitas kimia (Moore-Landecker, 1972). Dua hal yang umum berlaku mengenai pengaruh suhu, yaitu (1) kisaran suhu untuk kemungkinan terjadinya sporulasi lebih sempit dibandingkan dengan kisaran untuk pertumbuhan, dan (2) suhu optimum untuk pertumbuhan satu macam spora mungkin berlainan dari suhu optimum untuk produksi bentuk spora yang lain serta untuk pertumbuhan satu jenis cendawan (Hadi, 1989).

Pengaruh suhu terhadap efektivitas senyawa antifungi juga ditunjukkan dengan keadaan miselium cendawan patogen. Hasil pengamatan secara kasat mata pada biakan $R$. solani menunjukkan ciri miselium yang berbeda pada tiap suhu yang diberikan. Suhu $25^{\circ} \mathrm{C}$ menunjukkan ciri miselium yang pucat, kekuningan, tipis, transparan, dan tumbuh tidak merata. Miselium terlihat berwarna putih pucat kecoklatan dengan pinggiran berwarna merah jambu, tipis, dan transparan pada suhu $30^{\circ} \mathrm{C}$. Sedangkan pada suhu $35^{\circ} \mathrm{C}$ miselium menunjukkan ciri tipis, dengan warna jingga transparan dan tidak merata. Sementara itu, miselium cendawan pada suhu $40^{\circ} \mathrm{C}$ menunjukkan ciri transparan dengan pinggiran menebal, dan berwarna krem kekuningan (Fitri, 2013). Selanjutnya menurut Pelczar et al. (1986) keragaman suhu dapat mengubah proses metabolik tertentu dan morfologi sel. Semakin tinggi suhu menyebabkan efektivitas senyawa antifungi yang dihasilkan oleh bakteri cenderung menurun. Pertumbuhan cendawan di dalam PDA semakin baik karena efektivitas kerja senyawa antifungi menurun.

\section{KESIMPULAN}

Kemasaman (pH) media yang berbeda menyebabkan pertumbuhan koloni L. theobromae yang berbeda. Semakin rendah $\mathrm{pH}$ atau kemasaman semakin tinggi maka diameter koloni semakin kecil atau pertumbuhan miselium lebih lambat. Pertumbuhan optimum cendawan pada kisaran $\mathrm{pH}$ 5. Penyimpanan tubuh buah patogen penyebab kanker batang karet dapat menurunkan viabilitasnya. Semakin lama disimpan viabilitasnya menurun. Penurunan terbesar terjadi pada tubuh buah yang disimpan dalam tanah yang tidak steril dan penyimpanan cendawan di atas 120 hari masih memiliki viabilitas 80\%. Rekomendasi untuk membatasi perkembangan cendawan ini adalah perlu penurunan keasaman tanah dan pengendalian patogen secara intensif karena sumber infeksi penyakit kanker batang di lapangan akan selalu ada walaupun dalam kondisi patogen tertekan akibat tekanan biotik maupun abiotik.

\section{DAFTAR PUSTAKA}

Ajith, P.S., \& Lakshmidevi, N. (2010). Effect of volatile and non-volatile compounds from Trichoderma spp. against Colletotrichum capsici incitant of anthracnose on bell peppers. Nature and Science, 8(9), 265-269.

Agrios, G. N. (2005). Plant pathology. Fifth Edition. USA: Elsevier Academic Press.

Carlile, M.J., Watkinson, S.C., \& Gooday, G.W. (2001). The Fungi. London, UK: Academic Press.

Cochran, V.W. (1958). Physiology of fungi. New York, USA: J Wiley.

Deshmukh, A.J., Mehta, B.P., Sabalpara, A.N., \& Patil, V.A. (2012). In vitro effect of various nitrogen, carbon sources and $\mathrm{pH}$ regimes on the growth and sporulation of Colletotrichum gloeosporioides Penz and Sacc causing anthracnose of Indian bean. Journal of Biopest, 5, 46-49.

Fardiaz, S. (1987). Penuntun praktek mikrobiologi pangan. Bogor, Indonesia: Lembaga Sumber Daya Informasi, Institut Pertanian Bogor. 
Febbiyanti, T.R. (2017). Diagnosis dan status penyakit kanker batang pada tanaman karet di Sumatera Selatan (Disertasi), Institut Pertanian Bogor, Indonesia.

Febbiyanti, T.R., Wiyono, S., Yahya, S., \& Widodo. (2019). Lasiodiplodia theobromae fungus causing stem canker disease on rubber tree (Hevea brasiliensis) in Indonesia. Journal of Agronomy, 2019, 1-8. Doi: 10.3923 /ja. 2019.

Fitri, E. (2013). Pengaruh suhu, pH, dan konsentrasi terhadap senyawa bioaktif antifungi Ralstonia pickettii dalam menekan pertumbuhan Rhizoctonia solani, (Tesis), Institut Pertanian Bogor, Indonesia.

Gandjar, I., Samson, R.A., Vermeulen, K., Oetari, A., \& Santoso, I. (1999). Pengenalan Kapang Tropik Umum. Jakarta, Indonesia: Yayasan Obor Indonesia.

Hadi, S. (2001). Patologi hutan: perkembangannya di Indonesia. Bogor, Indonesia : Fakultas Kehutanan, Institut Pertanian Bogor.

Kaiser, C., van der Merwe, R., Bekker, T. F., \& Labuschagne, N. (2005). In-vitro inhibition of mycelial growth of several phytopathogenic fungi, including Phytophthora cinnamomi by soluble silicon. South Africa: South African Avocado Growers' Association.

Li, C., Yang, Z., Zhang, R.H.C., Zhang, D., Chen, S., \& Ma, L.J. (2013). Effect of pH on cellulase production and morphology of Trichoderma reesei and the application in cellulosic material hydrolysis. Journal of Biotechnology, 168, 470-477. Doi : 10.1016/j.jbiotec. 2013.10.003.

Moore-Landecker, E. (1972). Fundamentals of The Fungi. New Jersey, USA: Prentice-Hall, Inc
Nitzan, N., \& Tsror, L. (2003). Effect of temperature and $\mathrm{pH}$ on in vitro growth rate and sclerotial density of Colletotrichum coccodes isolates from different VCGS. Amer J Potato Res, 80, 335 - 339 .

Pal, K.K., \& Gardener, B.M. (2006). Biological control of plant pathogens. The Plant Health Instructor, 1-25. Doi: 10.1094/PHI-A-2006-1117-02

Pardo, E., Marin, S., Ramos, A. J., \& Sanchis, V. (2006). Ecophysiology of ochratoxigenic Aspergillus ochraceus and Penicillium verrucosum isolates. Predictive models for fungal spoilage prevention - a review. Food Additives and Contaminats, 23(4), 398-410. Doi : $10.1080 / 02652030500376102$.

Pelczar, M.J., Reid, R.D., \& Chan, E.C.S. (1986). Microbiology. Philippine : McGraw-Hill

Purwantisari, S., \& Hastuti, R.B. (2009). Uji antagonisme jamur patogen Phythopthora infestans penyebab penyakit busuk daun dan umbi tanaman kentang dengan menggunakan Trichoderma spp. Isolat Lokal. Bioma, 11(1), 24-32.

Punithalingam, E. (1976). CMI descriptions of pathogenic fungi and bacteria No. 519. England (GD): Commonwealth Mycological Institute

Raka, I.G. (2006). Eksplorasi dan cara aplikasi agensia hayati Trichoderma sp. Sebagai Pengendali Organisme Pengganggu Tumbuhan (OPT). Bali, Indonesia: Dinas Pertanian Tanaman Pangan UPTD Balai Proteksi Tanaman Pangan dan Holtikultura.

Raut, J.K., Suzuki, A., \& Yoshihara, M. (2011). Effects on environmental factors on basidiospore germination of ammonia fungi coprinus spp. Collected from different geographical areas. Mycoscience, 52, 300 - 311. 
Rosfarizan, M., Ariff, A.B., Hassan, M.A., \& Karim, M.I. (2000). Influence of $\mathrm{pH}$ on kojic acid fermentation by Aspergillus flavus. Pakistan Journal of Biological Sciences, 3, 977-982, In El-Aasar, S. A. (2006). Cultural Condition Studies on Kojic Acid Production by Aspergillus parasiticus. International Journal of Agriculture \& Biology, 4, 468-473.

Rosita, E., Linda, R., \& Khotimah, S. (2014). Kapang pada tingkat kematangan gambut yang berbeda di Kawasan Hutan Lindung Gunung Ambawang, Protobiont, 3(3), 10-16.

Saha, A., Mandal, P., Dasgupta, S., \& Saha, D. (2008). Influence of culture media and environmental factors on mycelial growth and sporulation of Lasiodiplodia theobromae (Pat.) Griffon and Maubl. Journal of Environmental Biology, 29(3), 407-410.

Sennang, N.R., Syam'un, E., \& Dachlan, A. (2012). Pertumbuhan dan produksi padi yang diaplikasi pupuk organik dan pupuk hayati. J. Agrivigor, 11(2), 161-170.

Sibounnavoung, P., Kalaw, S.P., Divina, C.C., \& Soytong, K. (2009). Mycelial Growth and Sporulation of Emericella nidulans, A New Fungal Antagonist On Two Culture Media. Journal of Agricultural Technology, 5(2), 317-324.
Smith D., \& Onions, H.S. (1994). The preservation and maintenance of living fungi. 2nd ed. London, UK: Commonwealth Agricultural Bereaux International.

Soesanto, L. (2008). Pengantar pengendalian hayati penyakit tanaman. Jakarta, Indonesia: Rajawali Pers.

Umezurike, G. (1979). The P-Glucosidase from Botryodiplodia theobromae mechanism of enzyme-catalysed reactions. Biochem J., 179, 503-507.

Waluyo, L. (2007). Mikrobiologi umum. Malang, Indonesia: UMM Press.

Wheeler, K.A., Hurdman, B.F., \& Pitt, J.I. (1991). Influence of $\mathrm{pH}$ on the growth of some toxigenic species of Aspergillus, Penicillium and Fusarium. International Journal of Food Microbiology, 12, 141-150. Doi : 10.1016/0168-1605(91)90063-U.

Zhao, H., Huang, L., Xiao, C.L., Liu, J., Wei, J., \& Gao, X. (2010). Influence of culture media and environmental factors on mycelial growth and conidial production of Diplocarpon mali. Letters in Applied Microbiology, 50, 639-644. Doi: $10.1111 /$ j.1472-765X. 2010. 02847.x. 